\title{
The Multimodal Analysis of Gender Stereotypes in the Indonesian Textbooks for Deaf Students
}

\author{
Alfina Fadilatul Mabruroh*, Gunarhadi, Herry Widyastono \\ Educational Technology Department, Faculty of Teacher Training and Education, Universitas Sebelas Maret, \\ Indonesia \\ "Corresponding author. Email: alfina2104@gmail.com
}

\begin{abstract}
Numerous studies on gender representation in Indonesian textbooks have portrayed gender stereotypes in textbooks that demonstrate gender inequality, such as sexual violence, sexism, and double burden. However, there are only a few studies on gender representation in textbooks dedicated to students who are deaf. This study aimed to analyze gender stereotypes in the Indonesian special senior high schools textbooks dedicated to deaf students, using qualitative method. The results of this study show that gender inequality existed in some of the textbooks. Gender inequality was mainly portrayed in the figures and the materials illustrated in the English learning textbook for Grade 11 dedicated to students who are deaf. The figures and the materials in the textbooks did not demonstrate equality of occupation for both genders. Since deaf students, who rely heavily on visual aspects during their learning, need to be exposed to materials that demonstrate gender equality to foster gender equality awareness, it is recommended for textbook designers to develop textbooks that illustrate gender equality.
\end{abstract}

Keywords: deaf textbooks, gender inequality, special education, Indonesian special senior high school.

\section{INTRODUCTION}

Deaf children were at risk of experiencing language delays because deaf children were not exposed to spoken language [1]. Deaf children also had difficulties understanding written texts due [2]. However, deaf children are accustomed to decode single words \& separate sentences, compared to decoding the entire text, which prevents deaf children from having language difficulties.

Language access can provide opportunities for deaf students to learn how to socialize, regulate their own behavior (impulse control, executive function), and maximize opportunities to master social cognition (understanding other people's perspectives) [3]. Deaf children with a moderate level of hearing loss need special help to improve their language skills in the special school [4]. Textbooks have an essential role in the teaching and learning process, which guides teacher's and learner's activities in many classrooms [5]. In the learning textbooks context, there are numerous studies into gender issues such as gender representation, gender stereotyping, and underrepresentation of females in school textbooks [6] [7] [8]. Many studies into gender representation in Indonesian textbooks portray gender stereotypes in textbooks that demonstrate the inequality of gender.

The research about the portrayal of women in textbooks for senior high school students in Indonesia study expressed gender biases and stereotypes through female characters and social actors [9]. Another study confirms gender bias in the prescribed Indonesian English language textbook for junior high school students revealed that portrayed gender bias or stereotypes in which these stereotypes are presented through visual and verbal texts. It suggests that designers construct male and female-dominated stereotypes in the English language textbooks[10]. Furthermore, a study that adopted corpus linguistics and critical micro semiotic analysis showed gender fairness encapsulated in gender-neutral vocabularies in both verbal and visual texts [11]. 
Study of the representation of gender stereotypes in Indonesian English language textbooks using language sexism and visual narrative representation depicted the social role of males is more predominantly presented than its female counterpart in both visualizations and written texts [12]. Gender issues such as gender stereotypes, gender bias, and sexism in textbook materials are essential to investigate since they will avoid gender misunderstandings by students [13], [14]. This study focuses on this study using multimodal to assert how the gender stereotype is represented in textbooks. Multimodal is a theory drawn on meaningmaking from social semiotic, where texts are understood as part of broader socio-cultural contexts [15].

Numerous studies into gender representation in textbooks portray gender stereotypes-however, only a few studies into gender representation in deaf learning textbooks. Textbooks have a very important role in the teaching and learning process. The values contained in a textbook have different meanings [16]. Students obtain information through textbooks included knowledge and values, to prevent gender inequality. More than $5 \%$ of the world's population, or 466 million people, have hearing loss, with a composition of 432 million adults and 34 million children. The disorder is defined as a condition in which the sense of hearing or ears, both one and two, cannot hear $25 \mathrm{db}$ (decibels). Hearing loss or deafness has an impact on speech and language. The hearing ability of the same child can differ from day to day, so some children with hearing loss rely on sight as their primary means of communication [17]. Although deaf students depend on vision, there is no evidence indicating that students are more likely to be visual learners or better visual learners than hearing students [18]. However, issues pertaining to deaf students are learners who have visual tools only to receive learning material necessary to give the best learning material. The condition of deaf students who have the more significant hearing losses will rely relatively more on vision than audition [19].

Based on the 2019 National Commission's Annual Notes 2019, sexual violence against women with disabilities, that data illustrates the deaf people require to be given the awareness of gender equality to prevent their risk of gender inequality in the future [20]. Deaf children in school need to access textbook containing gender equality. This is important to expose deaf children to knowledge and values to prevent gender inequality. To fill this empirical gap, this study aimed to obtain an analysis of gender stereotypes in Indonesian special senior high school textbooks. Research highlights some concerns for the English language and Indonesian language textbooks for deaf learning and focuses on how the visual and verbal texts depict gender stereotypes. This study is aimed at analyzing gender stereotypes in the Indonesian special senior high schools textbooks dedicated to deaf students.

\section{METHODOLOGY}

This study investigated gender stereotypes in the Indonesian special senior high schools textbooks using the qualitative method. The primary data were derived from the Indonesian government deaf learning material for senior high school to reveal the representation of gender in the textbooks. The data was collected through the website https://pmpk.kemdikbud.go.id/bukudigital/ which contains English language and Indonesian language textbooks in special education classes. Documents were studied to provide evidence of gender stereotypes in textbooks. The stereotypical gender is portrayed through verbal and visual texts through verbal and visual texts [21].

\section{RESULTS AND DISCUSSIONS}

The main data to reveal the representation of gender in the textbooks for deaf students were derived from the textbook for grades 10-11 since there is no learning material for deaf students in the grade 12 textbook.

\subsection{The Textbooks of $10^{\text {th }}$ Grade}

$\begin{array}{ll}\text { Nabil } & \text { : Putut, does your mother work? } \\ \text { Putut } & \text { : Yes, she does. She is an Elementary School teacher. } \\ & \text { And my father is an architect. } \\ \text { Nabil } \quad: \text { My mother is a housewife. She gives all her time to } \\ \quad \text { take care of the house and the children. My father } \\ & \text { works in a private company. }\end{array}$

Figure 1. Chapter 1 English language textbook. Tell Me about Yourself, Please!| page 15.

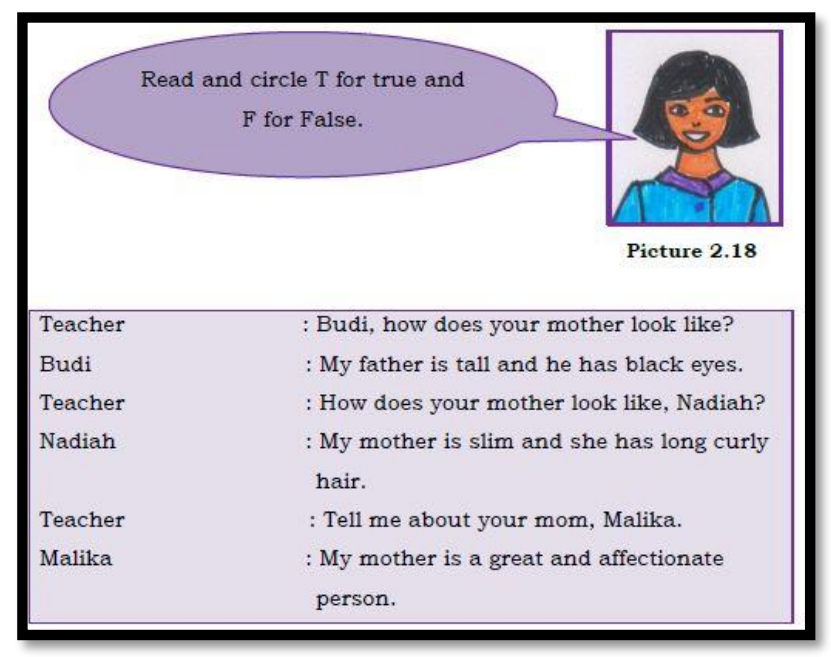

Figure 2. Chapter 2 English language textbook. My Parents are Great Person page 38.

There were six chapters in the English language textbook and three chapters in the Indonesian language textbook. The English language textbook consists of chapter 1 (Tell Me about Yourself, Please!), chapter 2 (My Parents are Great Persons), chapter 3 (Let's Go to 
the Library), chapter 4 (Congratulations on Getting First Rank, Nadiah!., chapter (No Smoking Please), and chapter 6 (You can be Amazing). The Indonesian language textbook consists of chapter 1 (Teks Iklan Sederhana), chapter 2 (Teks Pantun dan Syair Sederhana, and chapter 3 (Teks Narasi Sederhana). The English language textbook denotes stereotypical gender in terms of personality are presented in Figure 1.

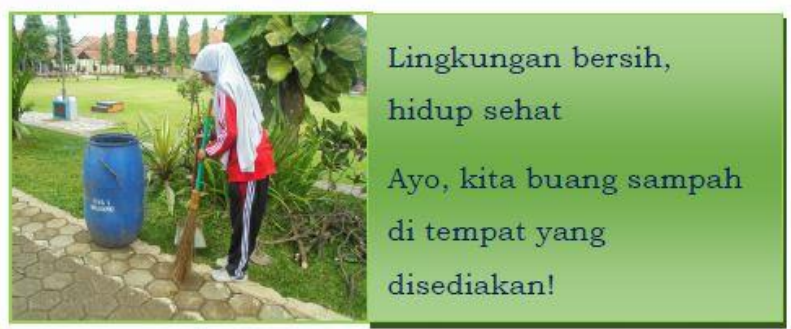

Gambar 1.1 : Iklan Lingkungan Bersih (Sumber : aryaldora'blog)

Figure 3. Chapter 1 Indonesian language textbook. Teks Iklan Sederhana, Please! Page 4 indicates a female student sweeping a yard.

"Kenapa sih kamu beda dengan cowok lain, biasanya cowok kan tidak suka belajar?" "Jelaslah aku berbeda, aku ini anak baik yang ingin menjadi orang sukses!" "Iya tah..." "Eh... jangan samakan aku dengan yang lain, bukannya sombong, bahkan banyak cewek yang ingin pacaran denganku tapi aku tolak mentah-mentah..." Lebai deh...!!"

Figure 4. Chapter 1 Indonesian language textbook. Teks Narasi Sederhana, Please!|page 65 indicates man personality associated with the lazy to learn.

\subsection{The Textbooks of $11^{\text {th }}$ Grade}

There are six chapters in the English language textbook and three chapters in the Indonesian language textbook. The English language textbook consists of chapter 1 (What Did You Do Yesterday?), chapter 2 (What Happened To Your Arm, Haidar?), chapter 3 (A Wonderful Trip), chapter (I'm Going To Make A Cake), chapter 5 (Dear Brina) Furthermore, in Indonesian language textbook consist of Chapter 1 (Teks Laporan Hasil Observasi), chapter 2 (Teks Esksplanasi), and chapter 3 (Teks Wawancara). The English language textbook denotes stereotypical gender in terms of personality as shown below.

There are 11 figures in the study document of this study. The figures consist of 1 figure from 10 grade of English textbook, two figures from 10 grade of Indonesian textbook, seven figures from 11 grade of an English textbook. The figures portrayed how males and females are in daily activities, characters, and jobs. According to egalitarian/feminist ideology, males and females are entitled to do anything job, be human beings, and have a character as to the natural human being. The 11-grade textbook learning displayed figures and examples of material that tend to subordinate female roles in daily activities based on four textbook learning. The fact that female is illustrated as DOIng domestic chores. This study revealed that gender stereotypes in the aspects of gender stereotypes. Figures three, five, six, eight, and nine illustrated how a woman always associates with domestic activities such as sewing, cooking, shopping, and ironing, while males associate with public activity.

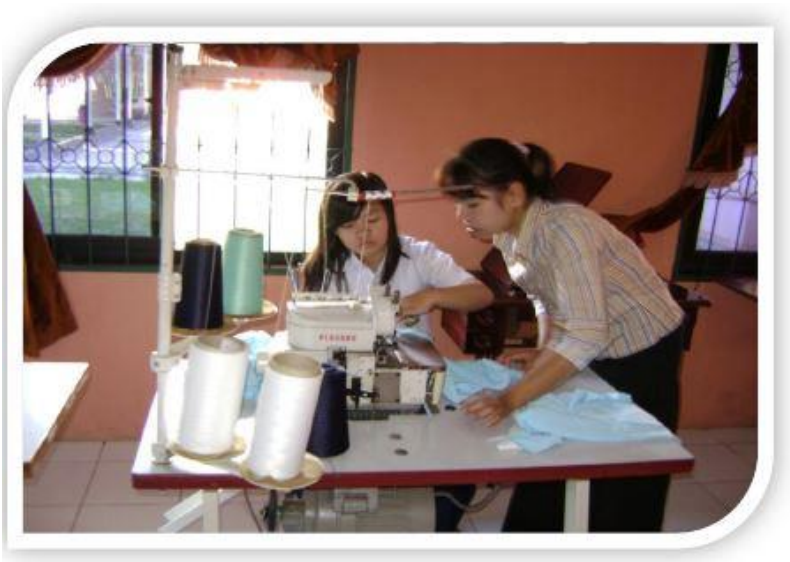

Figure 5. Chapter 1 English language textbook. What Did You Do Yesterday?! page 3 illustrates female students sewing.

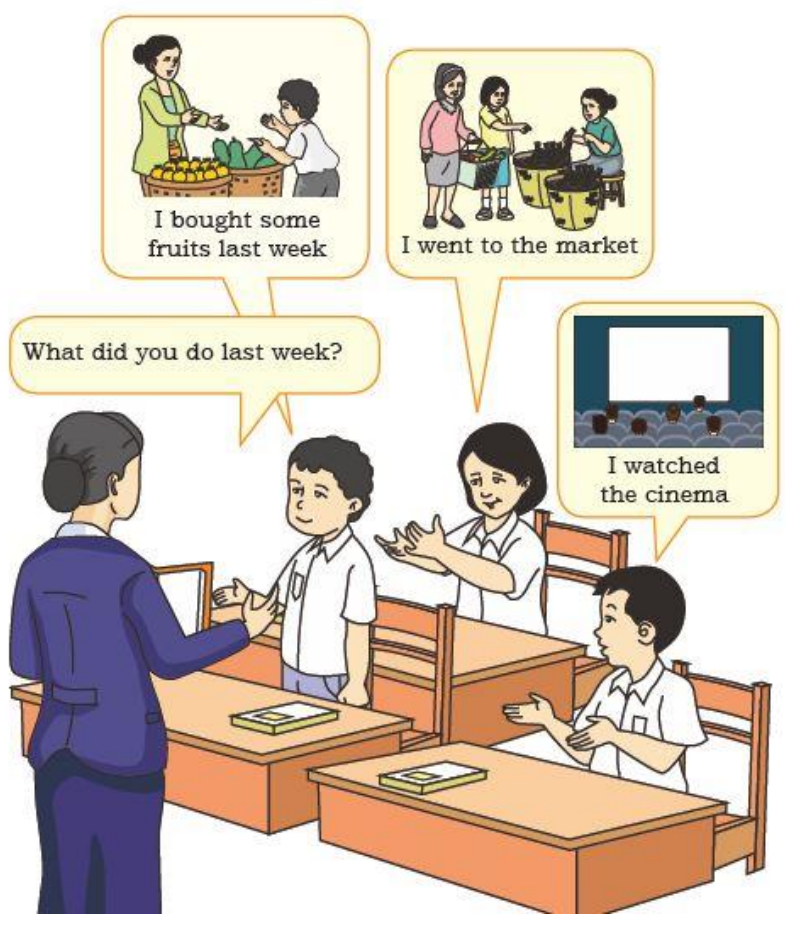

Figure 6. Chapter 1 English language textbook. What Did You Do Yesterday?! page 5 illustrates different activities between male and female students. 


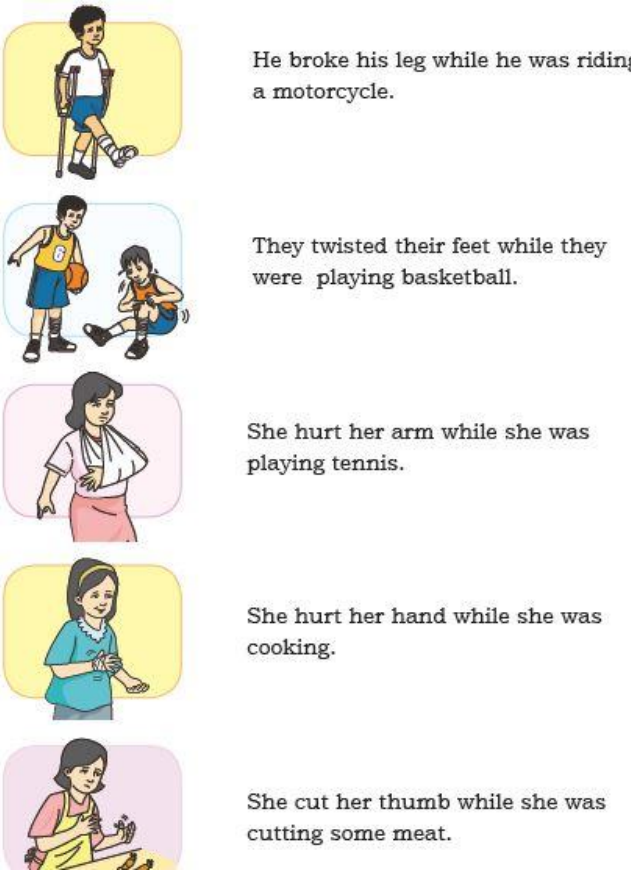

Figure 7. Chapter 2 English language textbook. What Happened To Your Arm, Haidar? Page 27 shows different incidents and the consequences of the incidents.
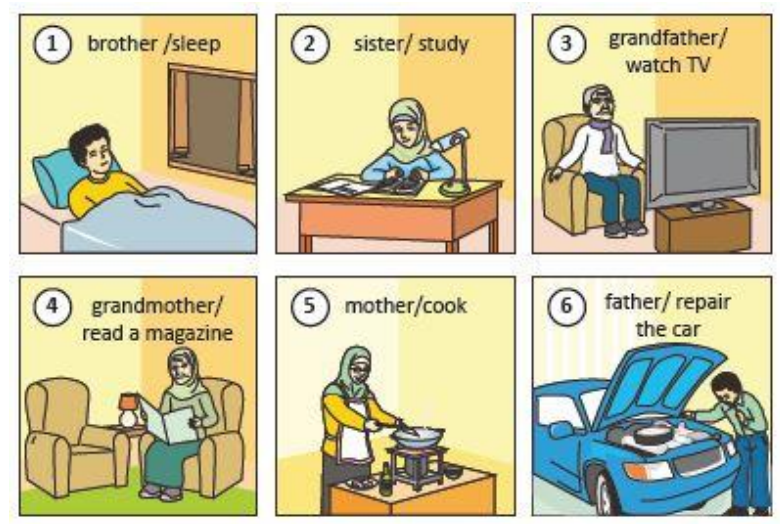

Figure 8. Chapter 2 English language textbook. What Happened To Your Arm, Haidar? Page 30 indicates the differences in the activity.
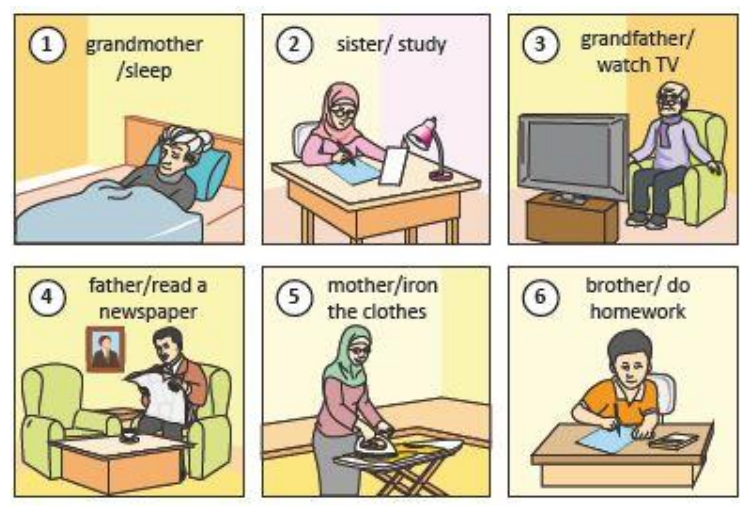

Figure 9. Chapter 2 English language textbook. What Happened To Your Arm, Haidar? Page 32 indicates differences in the activity.
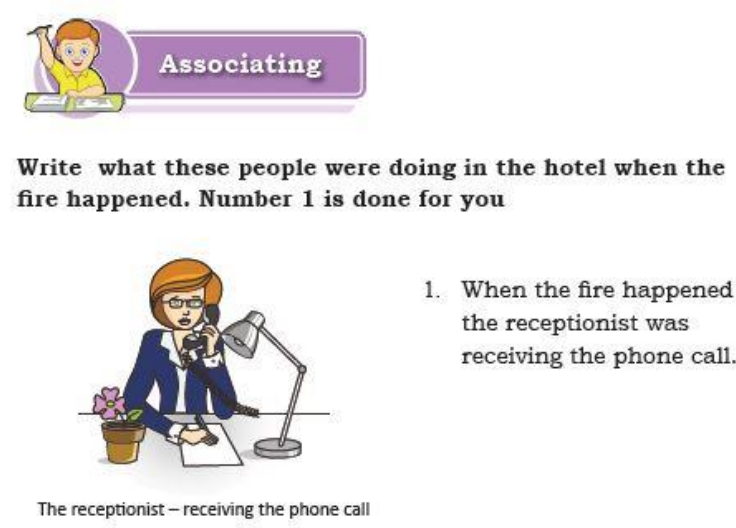

Figure 10. Chapter 2 English language textbook. What Happened To Your Arm, Haidar? Page 33.
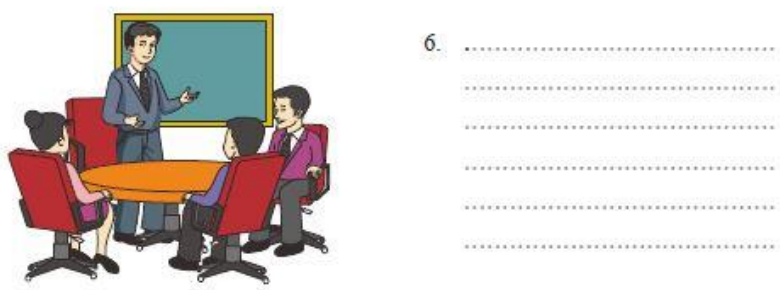

the manager - meeting

Figure 11. Chapter 2 English language textbook. What Happened To Your Arm, Haidar? Page 34.

The English language textbooks illustrated more gender stereotypes than Indonesian language textbooks. The English language textbooks portrayed domestic jobs to illustrate female domestic sphere activities such as sewing, cooking, shopping, ironing, that opposite to illustrated male activities which illustrated through the public job such as elementary school teacher and DOIng activities like a reading newspaper and repairing the car. In the 10-grade textbook, male students had given stereotypes as apathetic learners who showed in example material in figure 4.

\section{CONCLUSIONS}

It is concluded that gender inequality exists through how the female stereotypes portrayed in figures demonstrated material learning such as how the female does and how the differences occupation of female and male representation. The empirical evidence revealed that the persistence of gender inequality was more illustrated through figures and the material examples in the deaf English learning textbook for grade 11 than other textbooks.

As a guide of the learning process, textbooks have an essential role in the teaching and learning process, which guides teachers' and learners' activities in many classrooms. The authors conclude that there are no gender equality stereotypes in the Indonesian special 
senior high school textbooks. The figures and the material example have not consisted of the manifest of equality of work played by both males and females. The lack of understanding of gender awareness affected the weak power of communication and failed to use woman-power to show solidarity [22]. Gender awareness could play the main role in the prevention of gender abuse or affect gender equality in education. Deaf students, who rely on visual aspects, must be provided with figures and examples related to gender equality so that the learning process can inform gender awareness. Gender awareness will prevent them from gender inequality, such as sexual violence, sexism, double burden. It is recommended that textbook designers should be fully aware of gender equality when designing textbooks.

\section{AUTHORS' CONTRIBUTIONS}

AFM, G, and HW design and implement research, draft the manuscript, conduct the analysis and write the manuscript.

\section{ACKNOWLEDGMENTS}

We thank students and teachers of SLB in Surakarta for supporting this study with enormous data. We also thank Indonesia Endowment Fund for Education (LPDP) RI for supporting the study.

\section{REFERENCES}

[1] J. Meinzen-Derr, S. Wiley, R. McAuley, L. Smith, and S. Grether, "Technology-assisted language intervention for children who are deaf or hard-ofhearing; a pilot study of augmentative and alternative communication for enhancing language development," Disabil. Rehabil. Assist. Technol., vol. 12, no. 8, 2017, pp. 808-815. DOI: 10.1080/17483107.2016.1269210.

[2] O. Mich, E. Pianta, and N. Mana, "Interactive stories and exercises with dynamic feedback for improving reading comprehension skills in deaf children," Comput. Educ., vol. 65, 2013, pp. 3444. DOI: 10.1016/j.compedu.2013.01.016.

[3] I. W. Leigh and J. F. Andrews, Deaf People and Society: Psychological, Sociological and Educational Perspectives. Routledge.

[4] Haenudin, Pendidikan Anak Berkebutuhan Khusus Tunarungu. Jakarta: Luxima Metro Media, 2013.

[5] N. T. A. Sari, "Visible boys, invisible girls: The representation of gender inlearn english with tito (a critical discourse analysis of english language textbooks for primary school)," Indones. J. Appl. Linguist., vol. 1, no. 1, 2011, pp. 84-104. DOI: 10.17509/ijal.v1i1.101.

[6] A. L. Atchison, "Where Are the Women? An
Analysis of Gender Mainstreaming in Introductory Political Science Textbooks," J. Polit. Sci. Educ., vol. 13, no. 2, 2017, pp. 185-199. DOI: 10.1080/15512169.2017.1279549.

[7] J. F. K. Lee, "In the pursuit of a gender-equal society: do Japanese EFL textbooks play a role?," J. Gend. Stud., vol. 28, no. 2, 2019, pp. 204-217. DOI: $10.1080 / 09589236.2018 .1423956$.

[8] L. Namatende-Sakwa, "Networked texts: discourse, power and gender neutrality in Ugandan physics textbooks," Gend. Educ., vol. 31, no. 3, 2019, pp. 362-376. DOI: 10.1080/09540253.2018.1543858.

[9] B. Setyono and H. P. Widodo, "The representation of multicultural values in the Indonesian Ministry of Education and Culture-Endorsed EFL textbook: a critical discourse analysis," Intercult. Educ., vol. 30, 2019, no. 4, pp. 383-397. DOI: 10.1080/14675986.2019.1548102.

[10] R. P. D. Lestariyana, H. P. Widodo, and U. Sulistiyo, "Female Representation in GovernmentMandated English Language Textbooks Used in Indonesian Junior High Schools," Sex. Cult., vol. 24, no. 4, 2020, pp. 1150-1166. DOI: 10.1007/s12119-020-09752-2.

[11] Suwarno, S. Triyono, Ashadi, and W. Sahayu, "Gender Construction in the Indonesian Government-Distributed English Textbook: Combining Critical Discourse Analysis and Corpus Linguistics," Sex. Cult., vol. 25, no. 6, 2021, pp. 2158-2175. DOI: 10.1007/s12119-02109870-5.

[12] A. Tyarakanita, N. A. Drajati, D. Rochsantiningsih, and J. Nurkamto, "The Representation of Gender Stereotypes in Indonesian English Language Textbooks," Sex. Cult., vol. 25, no. 3, 2021, pp. 1140-1157. DOI: 10.1007/s12119-021-09813-0.

[13] L. Evans and K. Davies, "No sissy boys here: A content analysis of the representation of masculinity in elementary school reading textbooks," Sex Roles, vol. 42, no. 3-4, 2000, pp. 255-270. DOI: 10.1023/A:1007043323906.

[14] I. M. Maufiroh and I. Lukmana, "Representasi Gender dalam Buku Teks Bahasa Inggris Kelas X SMA di Indonesia: Analisa Linguistik Fungsional Sistematis," J. Penelit. Pendidik., vol. 20, no. 1, 2020, pp. 42-51. DOI: 10.17509/jpp.v20i1.24552.

[15] J. Callow, "Visual and verbal intersections in picture books-multimodal assessment for middle years students," Lang. Educ., vol. 34, no. 2, 2020, pp. 115-134. DOI: 10.1080/09500782.2019.1689996.

[16] H. P. Widodo, "A Critical Micro-semiotic Analysis of Values Depicted in the Indonesian Ministry of 
National Education-Endorsed Secondary School English Textbook," 2018, pp. 131-152. DOI: 10.1007/978-3-319-63677-1_8.

[17] W. L. Heward, S. R. Alber-Morgan, and M. Konrad, Exceptional Childern An Introduction to Special Education. 2017.

[18] M. Marschark, C. Morrison, J. Lukomski, G. Borgna, and C. Convertino, "Are deaf students visual learners?," Learn. Individ. Differ., vol. 25, 2013, pp. 156-162. DOI: 10.1016/j.lindif.2013.02.006.

[19] M. Marschark et al., "Don't Assume Deaf Students are Visual Learners," J. Dev. Phys. Disabil., vol. 29, no. 1, 2017, pp. 153-171, DOI: 10.1007/s10882-016-9494-0.

[20] M. Winarsih, L. D. Wahyuni, and U. Nanik, "Reproductive Health Animations as Efforts to Prevent Sexual Harassment in Deaf Students," JPI (Jurnal Pendidik. Indones., vol. 9, no. 3, 2020, pp. 525. DOI: 10.23887/jpi-undiksha.v9i3.24916.

[21] V. Leeuwen, Discourse and practice: New tools for critical discourse analysis. Oxford: Oxford University Press, 2018. 